\title{
The earliest recorded plant virus disease
}

\section{Pathogenic DNA paints summer foliage gold, and inspired a poet over a millennium ago.}

T he Man'yoshu, meaning 'collection of ten thousand leaves', is the largest and earliest anthology of Japanese poetry - it contains over 4,500 poems written between the early seventh century and the middle of the eighth century, and provides a glimpse of Japanese life during that period. One poem, attributed to the Empress Koken and written in the summer of $752 \mathrm{AD}$ (Fig. 1 ), describes the autumnal appearance of eupatorium plants in summer ${ }^{1}$ and is reputedly the earliest written record of the symptoms of a plant virus disease ${ }^{2}$. Here we show that a geminivirus and an accompanying satellite component isolated from affected eupatorium plants are together responsible for the spectacular foliar display that was first noted by the Empress more than a millennium ago.

Eupatorium plants in Japan frequently exhibit a striking yellow pattern on their leaves during summer ${ }^{3}$, a phenotype that has been correlated with the presence of a geminivirus named eupatorium yellow-vein virus $(\text { EpYVV })^{4}$. Because only a single genomic component had been reported for EpYVV, we suspected that the plants might be further infected with a DNA $\beta$-satellite component that is similar to those discovered in

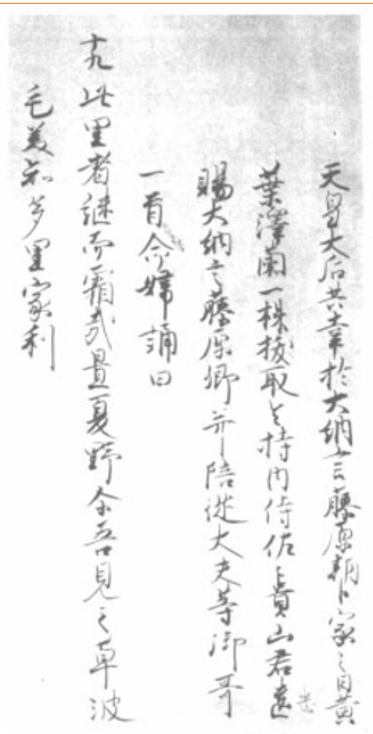

Figure 1 An early handwritten version of a poem by the Empress Koken describing the autumnal feel of the yellow leaves of eupatorium plants (translated here as grass) growing in summer ${ }^{1}$. The text reads: "Perhaps it does frost/ In this village morn by morn/ For the grass I saw in the field of summertime/ Has already turned yellow". The poem, taken from the Rui-shu-ko-shu edition of the Man'yoshu edited by Atsukata Fujiwara (1071-1120), was provided by Nobuyuki Sakamoto and is reproduced by courtesy of the Nara University of Education, Japan. ageratum (a widespread weed) and cotton ${ }^{5,6}$.

Nucleic acids were extracted from affected plants (Eupatorium makinoi, isolate MNS2) originating from the Fukuoka Prefecture in Japan, and a satellite component was amplified from a circular DNA $\beta$ satellite template by using the polymerase chain reaction with divergent primers ${ }^{7}$ (clone pGEM-EYVV $\beta M 10$; GenBank accession number, AJ438938). These primers also amplified naturally occurring recombinants containing geminivirus and satellite sequences, which resembled those previously described ${ }^{8}$, facilitating the isolation of a circular geminivirus DNA component using divergent primers (clone pGEMEYVVAM1; accession number, AJ438936).

Sequence analysis indicated that the geminivirus is an isolate of EpYVV from the Kumamoto Prefecture ( $88 \%$ identity $)^{4}$ and is closely related to Japanese honeysuckle yellow-vein mosaic virus ${ }^{9}$, a geminivirus that also has an accompanying satellite component (our unpublished results). The eupatorium satellite component is distinct from those associated with diseased ageratum and cotton (56\% and 53\% identity, respectively), although they all contain similar genes and control elements ${ }^{5,6}$.

To test their infectivity, we constructed cloned tandem repeats of the geminivirus and $\beta$-satellite DNA components, and introduced them biolistically ${ }^{6}$ into eupatorium plants. Characteristic yellow-vein symptoms appeared in 5 out of 25 plants (in 2 experiments) from 3-4 weeks postinoculation (Fig. 2a), and the presence of both components in symptomatic plants was confirmed by Southern-blot analysis (Fig. 2b). The disease was transmitted between eupatorium plants ( 8 out of 15 plants in 3 experiments) using the whitefly Bemisia tabaci, which is responsible for transmitting the disease in the field. These results confirm the aetiology of the disease by fulfilling Koch's postulates ${ }^{10}$.

We have shown that the beautiful foliar symptoms in eupatorium plants are caused by a geminivirus-satellite disease complex. To our knowledge, the poem that appears in the Man'yoshu represents the first documented description of a plant virus disease. Although this observation is anecdotal, it implies that such disease complexes were prevalent before the advent of modern intensive agricultural practices, which have encouraged the spread and diversification of geminivirus diseases. Similar disease complexes have now been found in weeds, ornamental plants and economically important crops throughout Africa and

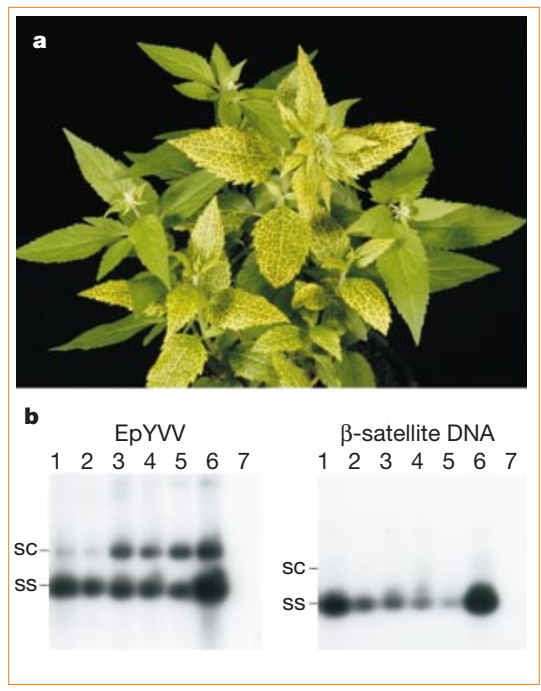

Figure 2 Confirmation of the aetiology of eupatorium yellow-vein disease. a, Diseased eupatorium plants exhibiting the yellow-vein phenotype, growing among healthy plants. The disease was transmitted by whiteflies that had acquired the virus from plants infected by geminivirus and satellite cloned components. b, Southern-blot analysis of DNA extracted from naturally infected plants (lanes 1 and 2), plants infected using either cloned components (lanes 3 and 4) or viruliferous whiteflies that had acquired viral progeny of the cloned components (lanes 5 and 6 ), and a healthy plant (lane 7). Blots were hybridized with EpYWV viral DNA (left) and $\beta$-satellite DNA (right) probes. SS, single-stranded DNA; SC, supercoiled DNA.

Asia ${ }^{11}$, indicating that they are diverse and widespread, and represent a serious threat to agriculture in the Old World.

Keith Saunders ${ }^{\star}$, Ian D. Bedford ${ }^{\star}$, Tetsukazu Yahara $\dagger$, John Stanley* ${ }^{\star}$ Department of Disease and Stress Biology, John Innes Centre, Norwich Research Park, Colney, Norwich NR4 7UH, UK

e-mail: john.stanley@bbsrc.ac.uk

$\dagger$ Department of Biology, Kyushu University, 6-10-1 Fukuoka, 812-8581, Japan

1. Suga, T. The Man'yo-shu: A Complete English Translation in 5-7 Rhythm (Kanda Inst. Foreign Lang., Tokyo, 1991).

2. Inouye, T. \& Osaki, T. Ann. Phytopath. Soc. Jpn 46, 49-50 (1980).

3. Yahara, T. \& Oyama, K. Oecologia 96, 310-315 (1993)

4. Onuki, M. \& Hanada, K. J. Gen. Plant Pathol. 66 , 176-181 (2000).

5. Saunders, K. et al. Proc. Natl Acad. Sci. USA 97, 6890-6895 (2000).

6. Briddon, R. W. et al. Virology 285, 234-243 (2001).

7. Briddon, R. W., Bull, S. E., Mansoor, S., Amin, I. \& Markham, P. G. Mol. Biotechnol. 20, 315-318 (2002).

8. Saunders, K., Bedford, I. D. \& Stanley, J. Virology 282, 38-47 (2001).

9. Osaki, T., Kobatake, H. \& Inouye, T. Ann. Phytopath. Soc. Jpn 45, 62-69 (1979).

10. Koch, R. Mittheilungen aus dem Kaiserlichen Gesundheitamte Vol. 2 (1884).

11. Mansoor, S., Briddon, R. W., Zafar, Y. \& Stanley, J. Trends Plant Sci. 8, 128-134 (2003).

Competing financial interests: declared none. 